\title{
Measuring the Impact of BRAC Microfinance Operations: A Case Study of a Village
}

\author{
Mohammad Kamal Hossain \\ Assistant Professor, Department of Accounting, National University, Gazipur, Bangladesh
}

Tel: 44-788-275-8527_E-mail: karunu2003@yahoo.com

Received: February 2, 2012

Accepted: February 23, 2012

Published: April 1, 2012

doi:10.5539/ibr.v5n4p112

URL: http://dx.doi.org/10.5539/ibr.v5n4p112

\begin{abstract}
The study attempted to measure the impact of BRAC microfinance operations on the livelihood of the borrowers of a sample village. With the purpose of measuring the impact of microfinance, randomly 208 people having minimum three-year attachment with BRAC microfinance operations were selected from a village. Primary data were collected by a semi-structured questionnaire, and both qualitative and quantitative data were used to assess the efficacy of microfinance operations. Findings of the study suggest that the overall impact of microfinance operations is positive. Borrower's income and their contribution to the family expenditures increased significantly after joining BRAC. However, the income increased shows that the borrowers have been able to intersect only the extreme poverty line while the moderate poverty line is yet to be exceeded. On the other hand, there is a moderate impact observed in the creation of employment opportunity. In addition, the sample clients have been able fairly to employ themselves into self-employment activities which generate higher income. However, impact on savings and improvement of borrowers' dwelling house's condition is less significant. The volume of monthly savings is not significant, but the attitude of the borrowers towards savings is noticeable.
\end{abstract}

Keywords: Microfinance, Impact, Poverty alleviation, Livelihood, Microfinance institutions (MFIs), Socioeconomic development

\section{Introduction}

"Around the world, in rich or poor nations, poverty has always been present" (Shah, 2008). According to the World Bank, 1.4 billion people live in poverty across the world (based on 2005 PPP), which are nearly $25.2 \%$ of the world population (Bauer et al., 2008). However, the extreme poverty (based on $\$ 1.25$ ) was reduced worldwide from $52 \%$ in 1981 (1.9 billion people) to $26 \%$ in 2005 (1.4 billion people) (ibid). Global poverty reduction was mainly driven by China (ibid), which has reduced the world's poverty rate, and excluding china, the world poverty fell only by around $10 \%$ (Shah, 2009).

The problem of poverty and approaches to reduce it remain the most pressing dilemma in the international development debate. However, many programs have been undertaken so far at macro and micro level to eradicate poverty. Some programs are taken globally by the United Nations, World Bank and IMF; some are in regional level by the regional financial institutions like the Asian Development Bank (ADB), Islamic Development Bank (IDB). In addition, every country suffering from poverty has also taken initiatives at the national level to alleviate poverty by the respective national governments and non-government organisations (NGOs). The World Bank, IDB or ADB are seen to take programs for a period of time on a project basis, sectoral orientation or to tackle seasonal poverty sufferings. At the end of the period, projects are found to be shut down and the poverty alleviation programs get stopped as well. Poverty alleviation is a continuous process, and a long term program is inevitable for success in this regard. Microfinance institutions (MFIs), at the non-government level, are found to adopt such types of long term continuous process for poverty alleviation. For instance, Grameen Bank, BRAC, ASA, Proshika are some of NGOs of Bangladesh have been working last couple of decades with a view to eradicate poverty economically and socially.

The methodologies and programs of MFIs began to spread around the world as microfinance proved a viable method to alleviate poverty. "From 2004 to 2008 microfinance enjoyed unprecedented growth in emerging markets. According to data from the Microfinance Information Exchange (MIX), the sector expanded at historic rates, with average annual asset growth of 39 percent, accumulating total assets of over US\$60 billion by December 2008" (Chen, Stephen \& Xavier, 2010). Currently 1000 to 2500 MFIs are serving some 67.6 million clients around the world (Sengupta \& Aubuchon, 2008). So the global picture regarding the outreach of microcredit demonstrates the contributions made by the program to poverty alleviation (Ahmed, 2004). 
There are good reasons to believe that microfinance makes the socio-economic conditions better for the poor. For instance, "the credit program of MFIs is highly successful, which is evidenced by the high repayment rate, awareness generated among the target group and beneficial developmental impact created on the receivers of the credit" (Reddy, 2000). However, some critics disagree that poverty cannot be eradicated with a tiny amount of money provided by MFIs; rather it implicates the poor in the long debt cycle. The answer to this criticism is found in a statement given by Adam Smith (1937; cited in Ahmed, 2004) in his Wealth of Nations. He said "when you have got a little, it is often easy to get more. The great difficulty is to get that little". The economic condition of the destitute poor is so lamentable that they do not have that little amount as well. That little amount is the requirement at the doorsteps of the poor at the right time to help them facilitate and start feasible income generating activities (Ahmed, 2004). The question is "how do the destitute poor people get hold of that little amount"? Only MFIs provide that little amount of money and the poor will be able to make it bigger amount.

\subsection{BRAC's Microfinance Programs}

BRAC (Bangladesh Rural Advancement Committee), as a non-government organisation (NGO) has emerged as one of the forerunners in the field of development cooperation after the liberation war of Bangladesh. It was founded in 1972 at Sulla village in Sylhet district of Bangladesh in response to the humanitarian needs of thousands of refugees returning to their homes after the war (Ahsan, 2005).

BRAC targets the landless people who are living below the poverty line, with particular focus on women, whose lives are dominated by illiteracy, disease and malnutrition. Their socio-economic empowerment is the primary focus of BRAC activities. With a view to this, collateral free loans, ranging from Tk. 1000-10,000, are disbursed to these members, which are repayable within one year. However, some loans such as house building loan are repayable in more than one year. During the initial period, BRAC arranges various training courses for village organisation (VO) members with a view to developing their skills. The VO members mostly engage, according to their own choice, in various income generating activities such as poultry, livestock, vegetable cultivation, fish culture, plantation, sericulture, small trade including grocery shops and restaurants (Islam, 1996).

BRAC's development efforts are conducted in six main sectors: Economic Development Program, Health Program, Education Program, Social Development Program, Human Rights and Legal services and Disaster Management, Environment \& Climate Change (BRAC at a glance, 2009). At present, BRAC's microfinance network covers all the districts of Bangladesh by as many as 293,016 village organisations (VOs) with 8.09 million VO members (ibid), $93 \%$ of whom are women (BRAC net, n.d).

After successful starting out of BRAC microfinance operations in Bangladesh, it has crossed the national demarcation and established itself in the international level. At present, its activities have widened in Afghanistan, Sri Lanka, Tanzania, Uganda, Pakistan, and Southern Sudan. Moreover, BRAC plans to help the citizens of Sierra Leone and Liberia in rebuilding their lives after decades of disastrous civil wars (BRAC net, n.d). When the world will become free from hunger and poverty, BRAC's activities will get stopped. Until then, it will strive "to find practical and scalable approaches to eradicate poverty" wherever is found (ibid).

\subsection{Objectives of the Study}

The overall purpose of the study is to measure the impact of BRAC microfinance operations on the livelihood of the borrowers. In order to gain an understanding about the efficacy of the microfinance operations, this study addresses a number of aims:

(a) To what extent BRAC microcredit borrowers have been able to develop themselves economically. That is, to what extent their income, contribution to the family expenditure and savings has increased after being involved with BRAC microcredit operations.

(b) To what extent BRAC microcredit operations have been able to improve borrowers' dwelling house condition, to make them diverted to high income generating activities and to create employment opportunities.

\subsection{Limitations of the Study}

The study has been conducted with some limitations. Some of these are identified as follows:

(a) BRAC is a specialized non-government financial institution whose poverty alleviation programs are spread across the country. But the study was limited to only one village named Jaheedpur under Kumarkhali thana in Kushtia district of Bangladesh. So, the impact analysis is partial in the sense that the investigation has been carried out on only a small area of microfinance networks, as a result the question of representativeness of the sample may arise while interpreting the results. 
(b) It was difficult to figure out borrowers' income, expenditure and savings as the members of the households did not record data regularly and they were reluctant to respond to the questionnaire for fear of different difficulties. As a result, respondents gave answers with cautions and most of the time they presumed the amount of income, expenditures and saving which could be deviated from actual figures.

(c) The relative weight of data is not same as the length of attachment with BRAC of all borrowers are not alike. But the impact of microfinance has been measured on an average basis where the standard deviation of the results might be different for the groups of short and long year's attachment.

(d) A few numbers of sample respondents were found to receive credit and other economic facilities from more than one MFI simultaneously. Similarly, many respondents had other income sources before joining BRAC and this was also continuing after joining BRAC. The sample respondents were unable to separate income figure generated from BRAC microfinance operations from other sources. Therefore, the mere measurement of the impact of BRAC microfinance operations has thwarted to some extent because of overlapping.

\section{Literature Review}

Microcredit is being considered as an effective means of poverty alleviation. Though, there are considerable debates about the effectiveness of it and the characteristics of the beneficiaries who are benefited by it (Chowdhury, Mosley \& Simanowitz, 2004). The available literature concluded that microfinance has varied impacts on the livelihood of poor people. Argument in favor of microfinance is that microcredit have brought millions - especially women - out of poverty and prompted economic sustainability (Glazer, 2010). Their arguments are supported by independent studies which advocate that "microcredit has a host of positive impacts on families that receive it" (Yunus, 2004). Microfinance clients have been able to increase their household income, decreased economic vulnerability and in some cases, wipe out poverty completely. In addition, they have been enjoying better nutrition, health facilities and greater empowerment as result of microfinance operations (Swope, 2005). Murdock and Haley (2002) conducted an extensive research on microfinance and its impact where they found a plenty of positive impact of microfinance on poverty reduction "as it relates to (the first six of the seven) Millennium Development Goals". These observations were supported by the findings of an evaluation study commissioned by the ADB (2007) on the effect of microfinance operations on rural households and the status of women of Bangladesh, Philippines, and Uzbekistan. The study concluded that the microfinance projects had positive impacts on the status of women by generating higher volume of cash in the household, greater involvement in making major expenditure decisions and making savings, "ability to generate more income on their own and greater role in business decision making, acquisition of more skills and expanding their network of friends and support system, and increased acquisition of assets".

Some countries such as Nepal, Bangladesh, India, Vietnam, China and the Philippines have commissioned an industry assessment of MFIs. These assessments identified benefits of MFIs such as "better food security and nutrition, housing and health, school enrolments for children, women empowerment and mobility, higher average household income and/or a more secure and consistent cash flow over the year, higher levels of literacy, building of human capital and assets and community participation, self-employment and employment of family member, employment creation-employment of nonfamily labor" (Bedson, 2009). In a study conducted by Panjaitan-Drioadisuryo \& Cloud (1999) in Lombok, Indonesia, found that $90 \%$ of sample clients of Bank Rakyat Indonesia (BRI) increased their income by $112 \%$ and these families exceeded the poverty line. Only $10 \%$ respondents' income did not increase because of misusing the money by their husbands. Similarly, Ghalib, Malki \& Imai (2011) in their research attempted to examine whether microfinance reduced poverty and to what extent and which dimensions of poverty eased. Their study confirmed that microfinance programs improved significantly in household income, expenditure on healthcare, clothing, water supply and building a quality of dwelling house.

However, recent studies cast doubt on microcredit's effectiveness. Many studies suggest that the veracity of microfinance efficacy may be less attractive than the promise (Adams \& Bartholomew, 2010). Borrowers have been burdened with multiple loans at exorbitant rates of interest, often having to borrow from more than one MFI to make their microcredit payments (Glazer, 2010). Noreen (2010) however, found in her study a varied impact of microfinance on poverty alleviation where significant positive impact noticed on children education and enterprise financial performance, but mixed evidence on food security, household expenditures and household assets and less significant impact has been observed on housing and income smoothening of enterprise. On the other hand, Adams and Bartholomew (2010) examined the impact of microfinance from the perspectives of maize farmers in Nkoranza in the Brong Ahafo Region of Ghana and concluded that the impact of microfinance programs on both social and economic wellbeing was trivial. On the other hand, Okpara (2010), in a study on Microfinance Bank and Poverty Alleviation in Nigeria suggested that that microcredit "in recent times picked up momentum in the drastic reduction of poverty. Ten years after the introduction of microcredit in Nigeria, poverty was still increasing though at a 
decreasing rate with the increase of microcredit". However, continual increase of microcredit leads to radical reduction of poverty. Reasons which posed obstacles in the efficacy of microfinance program are identified as lack of entrepreneurial skills and adequate market of their products (Noreen, 2010) and misuse of loan by the male members-especially husband of the participants (Panjaitan-Drioadisuryo \& Cloud, 1999).

Many researchers have compared poverty scenario between clients and non-clients of microfinance and scenarios before and after joining microfinance interventions.

Bansal (2011) carried out a comparative study (participant vs. non-participant of microfinance) in Punjab, India that showed microfinance programs were successful to diversify the economic activities in rural areas and made participants engaged in economic activities which increased income of individual and household and reduced income inequalities, as a result of which they managed to extricate themselves from financial vulnerability and reduce level of poverty. The study also showed that microfinance programs empowered women economically, socially, psychologically and politically. These findings are supported by the results of other study carried out by Jegede, Kehinde and Akinlabi (2011) which discovered that there is a significant difference in terms of income between participants and non-participants of microfinance program. The participants' income significantly increased which changed their economic status compare to non-participants. The study also summed up that "microfinance institution is indeed a potent strategy of poverty reduction and a viable tool for supplying credit to the poor". Similarly, Setboonsarng and Parpiev (2008) carried out a research on microfinance and Millennium Development Goals in Pakistan. They drew a comparative impact assessment of microfinance between borrowers' households of Khushhali Bank (KB) and non-borrowers. They found strong positive impacts of KB borrowing on agricultural production, especially in animal raising activities and agricultural farming. KB clients possessed on average higher value of livestock, farm equipment and rental income from farm equipment than that of non-borrowers. However, they did not find any significant impact on non-agricultural enterprise, durable assets, consumption, education, health care and empowerment. On the other hand, Rahman et al. (2001) found in his study that average working day of the respondents before joining Grameen Bank microfinance operations was 136 man days in a year and after joining the Grameen Bank they worked average 298 man days in a year which referred to changing working days $199 \%$ higher than that of before joining.

The destitute people of villages suffer from hunger acutely, which is another dimension of poverty and they become happy if they are able to enjoy foods two or three times in a day. Several researches showed that microfinance operations freed them from hunger. Mina and Alam (1995) in a study suggested that $82 \%$ of respondents had self-sufficiency of food for 2-6 months and only $18 \%$ had for 6-7 months in a year before joining microfinance operation, while after joining the credit programs, the figures were just reverse to before joining the program. Rahman et al. (2001), however, revealed different statistics in their study that clients of microfinance operations spent a lesser portion of income to their family basic food items after joining credit program. They found that though the amount of expenses on food increased remarkably accounting for $274.41 \%$ higher than before joining operations, but after joining credit program, they were spending only $66.75 \%$ portion of income for their family basic food items, which was $18.84 \%$ lower than before joining credit program while significant portion (85.59 \%) of income would spend for that. The study also pointed study that no clients of microfinance had saving before joining Grameen Bank, but a remarkable advancement in saving was found after joining microcredit program. Moreover they found in their research that the value of all tangible resources of the clients went up by $955.9 \%$ at the survey year after joining Grameen Bank microfinance program. Though an insignificant change (only $13 \%$ ) was taken place in land ownership. But drastic change was observed in livestock and poultry after joining credit program, which was $1606.05 \%$ higher than before joining followed by house and modern amenities $(265.43 \%)$.

To sum up, most of the researchers found that microfinance has had a significant effect on the livelihood of the participants. Some critic researchers, however, argue that it is not a silver bullet or panacea of poverty alleviation. Indeed, the critics have raised a question if microfinance alleviates poverty at all (Swope, 2005) and if so, to what extent and which aspect of poverty has been eased.

\section{Methodology of the Study}

"The industry has yet to standardize the framework used for such assessments. Parameters and frameworks vary depending on who commissions the assessment - the government, donors, internal industry stakeholders or investors" (Bedson, 2009). Different methods were applied in different researches to measure the impact of microfinance operations. In the early 1980s, Hossain (1984; cited in Develtere \& Huybrechts, 2002) used a method known as "before and after" scenarios analysis of the borrowers. The same author (1998; cited in Develtere \& Huybrechts, 2002) used another method to measure the impact by using member perception. More recently, some authors have used income and consumption as dependent variable for the measurement of the impact of microfinance operations 
(Develtere \& Huybrechts, 2002). In this study, the earlier method, "before and after", mentioned above, has been used to assess the impact of microfinance operations of BRAC on the livelihood of the beneficiaries.

In this study, both primary and secondary data were used. Primary data were used to assess the impact of microfinance operations. With a view to collect primary data, a village (sample unit) named Jaheedpur under Kumerkhali police station in Kushtia district of Bangladesh was selected using probability sampling procedures. More than 200 clients having minimum 3 years experience of BRAC microfinance operations were brought under the field survey by using stratified sample technique. Participants of microfinance operations of BRAC were interviewed with a semi-structured questionnaire, which included two sections; the first section consisted of general information about the respondents such as name, age, educational back ground, marital status, years of attachment with BRAC microfinance operations, amount of loan taken etc. In the second section, they were asked about the routine information regarding microcredit and its economic return to measure the impact. Including these, changes of occupation, dwelling house, income and expenditure, attitude to saving etc. were remarkable.

In this study, several secondary data were also used for describing and demonstrating current profile of BRAC microfinance interventions. The secondary data were collected from different books of microfinance, journal articles, and official publications of different microfinance institutions, website, magazines, newspapers, published thesis papers of the scholars, published dissertation papers of the graduates etc.

After collecting primary data, they were tabulated using a data matrix sheet and all data was recorded using numerical codes. Various statistical measures such as tally, frequency distribution, and mean were used in describing the variables. Moreover, charts and data table were used to illustrate the analysis of findings.

\section{Analysis of Findings}

Microfinance programs, first and foremost, concentrate to economic development followed by social development of the borrowers. Because it is unanimously recognized that social development will not be effective without economic development by easing poverty. "Traditionally, development initiatives have been synonymous with raising people's income and employment opportunities, increasing their consumption and helping them build assets and accumulate savings" (Galib, 2007). Poverty reduction programs are considered to deal primarily with aiding borrowers for tangible, material gains (ibid).

However, "impact assessments are plagued with methodological issues" (Bedson, 2009) as it is difficult to measure absolute impact of microfinance operations on the livelihood of the destitute people because of having different measurement processes and lack of unanimity about the definition of poverty, "difficulty of obtaining a comparable control group, disentangling credit benefits from the benefits of complementary development inputs of social programs, and limiting the number of attributes that define an assessment are but a few of the constraints" (ibid). There are some common variables to measure the impact of a typical microfinance programs "includes income, diversity of income sources, volatility of income, employment generation, assets acquisition, volatility of household consumption, education for children, poverty reduction, women empowerment and reduction in social exclusion of women" (Choudhury, 2001). In this study, some of the common variables mentioned above have been used to measure the impact of BRAC microfinance operations.

\subsection{Impact on Occupation}

Three major constraints that prevent the disadvantaged poor people from improving their lives are lack of access to formal financial services, "absence of self-employment opportunities and lack of skills" (Shamsuddoha, 2005). "BRAC realized that if different employment opportunities can be created, along with sufficient training and refreshers for capacity development, the poor could be linked to the mainstream economy which would ultimately bring them out of poverty" (ibid). With a view to employment generation, BRAC provides micro financial services and renders training and skills development services.

Table 1 presents overall employment and occupation scenario of the sample respondents before and after joining BRAC microfinance operations. Data shows that before joining microcredit scheme a significant number (32\%) of respondents were unemployed. While no one was seen as an unemployed after joining microcredit scheme, which can be considered to be worth mentioning and drastic transition in employment scenario. On the other hand, before being involved with BRAC's microcredit, around $31 \%$ of respondents were involved in low paid works. However, the number plummeted (about $77 \%$ decreased compare to before joining) after joining BRAC, though still there were $7 \%$ borrowers employed in low paid works in the survey year. While only around $37 \%$ of respondents were self-employed before joining BRAC. The number increased sharply after participating credit scheme which accounted for around $93 \%$ (161\% greater than before joining). Therefore, it is observed that participants have 
diverted significantly to self-employed activities after joining BRAC microcredit programs which lead them to be self-reliant and good means of livelihood.

\subsection{Impact on Income}

"Poverty reduction takes place when the poor people are able to generate income" (Subrahmanyam, 2000). The income of the rural poor people is not sustainable as their income depends heavily on seasons. Especially "at the harvesting time, their income reaches peak, while in other periods, they have almost nothing" (Develtere \& Huybrechts, 2002). On the other hand, women workers suffer from gender inequality in getting jobs and wages compared to men. They are not offered jobs equally and/or if offered, they are not paid as much as is paid to male workers despite doing the same or similar works, which brings household average income level down. Therefore, poverty is strongly associated with income inequality (Deolalikar, 2002).

BRAC emphasizes on sustainable income generation which is a pre-condition of getting rid of poverty. Table 2 shows the changes of average per capita monthly income of the sample respondents before and after joining BRAC. Data reveals that the average per capita monthly income before joining BRAC microfinance operations was Tk. 1116.67. While after joining BRAC micro loan scheme, a tremendous change is observed in the income scenario, where average per capita monthly income has sharply raised to Tk. 3923.56 which is almost $254 \%$ higher than before joining BRAC. It is apparent in the data table that on an average $100 \%$ of sample respondents' income has increased. Field survey reveals that the more years' members are attached with BRAC microfinance operations, the more amount of loan they have taken and their income level have increased accordingly. Data relating to income, amount of loan taken and length of attachment with BRAC operations (Table 7) suggest a significant positive impact on income with cumulative loan size and length of association with BRAC.

The World Bank (2008; cited in Bauer et al., 2008) defines extreme poverty as living on less than US \$1.25 (PPP) per day, and moderate poverty as less than $\$ 2$ a day. Accordingly, a person is thought of extreme poor who earns less than Tk 2587 (Tk.69 $\times \$ 1.25 \times 30$ days) and moderate poor whose earning is less than Tk 4140 (Tk $69 \times \$ 2 \times 30$ days) in a month (Note 1). Table 2 shows that the average income level before joining BRAC lies underneath of the income level indicating extreme poverty while after joining BRAC, the average income level lies above the income level indicating extreme poverty but underneath of the income level indicating moderate poverty. The statistics categorically demonstrates that the sample borrowers had been suffering from extreme poverty before joining BRAC. While they have been able to cross the extreme poverty line but failed to exceed the moderate poverty line after joining BRAC.

\subsection{Impact on Expenditure}

The daily family expenditure depends heavily on household income capacity. Usually the more income leads to more expenditure. The income and expenditure scenario of the poor household is hand to mouth. Households consists of 3 to 5 or 6 members depend only on one or two members' income by which need for basic foods, clothing, health care, education etc. of all members are to be fulfilled. They always prioritize in meeting basic needs, such as eating 2 or 3 times in a day, and if anything is left thereafter they consider for meeting other demands.

Table 3 shows contributions to the family expenditure of the sample respondents before and after joining BRAC microfinance operations. Data revealed that average monthly contributions to family expenditure of the sample respondents before joining BRAC was Tk. 1019.30, out of which most of the expenditure were ( $88 \%$ ) incurred in meeting basic food. Only a minor portion of expenditure was made for clothing (5\%) and a trivial portion for children's education and other purposes. The contribution to their family expenditure has gone up to Tk 3769.30 after joining microcredit programs, which is $270 \%$ higher than before joining BRAC. An insignificant portion of expenditure was made in the health care (5\%) and entertainment purposes (3\%) after joining microcredit program where there was no allocation before joining which can be thought of a positive transition of their lives.

Data illustrated an important fact that though the amount of expenditure on basic food items increased, but the percentage of expenditure to that purpose reduced by $25 \%$ with the borrower's increased contribution to their family expenditure and expenditure on clothing; children's education and other purpose increased remarkably. Another important thing was found in this study that the contribution to the family expenditure went up with the increase of respondents' income. Average contribution to the family expenditure of the sample respondents increased about Tk.2750 per month with the increase of monthly income on an average of Tk.2807 (Table 2) after joining BRAC.

\subsection{Impact on Savings}

Savings play a vital role in building confidence of the rural people. It can be used as the substitute of insurance where social safety nets are hardly ever existent for the poor of the developing countries (Morduch, 1999; cited in Hudon, 2006). MFIs emphasize on savings with a view to accumulate capital for further investment to "ensure 
security and sustainability when the members leave" (Hossain, 2008) MFI and to tackle unexpected event(s) like cyclone, physical accident etc or different risks such as life-cycle risks, business risks, and emergency risks etc (Bedson, 2009). Because, poor people are the most defenseless to risks and "yet the least protected against" the consequences of different kind of risks. "These risks are compounded when they aren't adequately prepared with a savings cushion to mitigate them" (ibid). The poor people have the desire to save and the demands for secure and convenient savings services are often even stronger among them than are credit services (Wright, 1999). However, "most poor people have little savings and even less discretionary income" (Bedson, 2009) as the reality is that their current consumption often exceeds current income.

The study made an attempt to ascertain attitude of the borrowers towards savings and data in this regard was presented in Table 4. The study revealed that the average monthly savings of the sample respondents were only Tk. 9.14 before joining BRAC. The number of respondents having monthly savings was negligible figure where the largest portion (79\%) was net dis-savings position. While after joining BRAC microcredit programs, $100 \%$ respondents are under savings bracket and in the survey year the monthly average savings has gone up to Tk. 52.27 which is $471.88 \%$ higher than before joining microcredit scheme. One thing is visible in this study that though the volume of savings has not increased significantly, however, the attitude of the borrowers towards savings has improved with heartening rate.

\subsection{Impact on Employment Generation}

In Lesser Developed Countries (LDCs) like Bangladesh, most of the household's income depends only upon one income earner. MFIs contribute directly or indirectly to increase their income bracket by creating new employment opportunities. "Microcredit delivery to women assists to generate employment for the able bodied male members who may not have access to the credit facility" (Choudhury, 2001).

Table 5 exhibits the statistics of employment generation upon participated in the BRAC microfinance operations by the sample respondents. The study found that there were only 276 income earners in the households of the sample respondents before joining BRAC microcredit programs, where most of the households (68\%) were depended only upon one income earner. The numbers of households having 2 or 3 income earners were $24 \%$ and $8 \%$ respectively. The scenario of employment generation has turned out to be better after joining BRAC. Data shows that as many as 148 new employment positions have created which is $54 \%$ more than the number of employment before joining BRAC. A high increase ( $5 \%$ of households) of employment generation is observed where there are 4 income earners of 10 households in the survey year whilst there was no household having 4 income earners before joining BRAC. On the other hand, number of households having only one earner has reduced by $62 \%$ and number of households earning 2 or 3 members has increased sharply. These statistics therefore, categorically illustrate positive impact of microcredit programs in the creation of employment opportunity.

\subsection{Impact on Dwelling House}

Housing condition is an important determinant to judge people's living standard and accumulated wealth position. The out looking of houses built in urban is quite different from that of rural areas of Bangladesh. Generally, rural houses are seen to build with thatch, bamboo, clay and tin. Residents of these kinds of house persistently remain in danger caused by natural (storms or cyclone etc) or unnatural (robbery or theft etc) turbulence. Moreover, they suffer recurrently from normal rainfall as most of these houses usually have several holes and remain all the time warm and dark as there is no proper ventilation system (Khondkar, 1999). While urban houses are built with bricks permanently that protect residents from dangers.

Table 6 presents housing condition of the sample respondents before and after joining BRAC microfinance operations. Table shows that most of the respondents' $(87 \%)$ houses, before joining microcredit programs, are fully made by clay and thatch which are risky for living. This number has reduced by $36 \%$ after joining BRAC which cannot be said significant improvement. On the other hand, $13 \%$ houses were made with clay wall and tin roof before joining BRAC while this figure went up by $162 \%$ after joining BRAC which could refer outstanding development. Only $11 \%$ of sample respondents have been able to make their houses by fully tin after joining BRAC where there was no respondent possessed this kind of house before joining BRAC which can be measured a slight improvement in the dwelling house though they are not still free from dangers.

\section{Conclusion and Recommendations}

The study has illustrated the impact of BRAC microfinance operations on the livelihood of the borrowers. The above analysis shows that the overall impact of BRAC microfinance operations on the livelihood of the borrowers is positive. Though, in some cases the impact is limited or not significant. In the case of changes of employment (occupation) pattern, the sample respondents have been able moderately to employ themselves into higher income 
generating activities. The study found that as many as $119(161 \%)$ sample borrowers have diverted themselves to self-employed activities which generates higher income, and there were $15(7 \%)$ of respondents still employed in low paid works after joining BRAC. Borrower's income and their contribution to the family expenditures have increased significantly after joining BRAC. The average contribution to the family expenditure of the sample respondents gets increased by the amount of Tk. 2750 (270\%) per month with the increased of monthly income on an average by Tk. 2807 (254 \%) per month after joining BRAC. Borrowers having long periods of attachment with BRAC microfinance program show high volume of income compared to borrowers having short period of attachment. However, this income increase is not good enough to meet all their basic needs. The income increase shows that the borrowers have crossed only the extreme poverty line though the moderate poverty line is yet to be exceeded. On the other hand, there is a moderate impact observed in the creation of employment opportunity. As many as 148 income earners increased i.e. $54 \%$ new employment opportunity has created after joining BRAC microfinance programs, while a number of households (22\%) have failed to create new income earner (still depend on one income earner) despite involving themselves into BRAC microcredit programs.

The cases where the impact of BRAC microfinance program finds less significant are savings and improvement of borrowers' dwelling house condition. Volume of savings has increased with insignificant rate (Tk. 43.13 per month); however, the attitude of all borrowers towards savings has improved after joining BRAC. On the other hand, a trivial change noticed in the improvement of the condition of dwelling house where most of the borrowers still remain in danger of natural and unnatural turbulence.

The plan, however, aiming for poverty alleviation designed by BRAC suffers from many limitations, such as providing very tiny amount of loan by which eliminating extreme poverty is possible while moderate poverty is not. Therefore, the following recommendations could be considered which could bring robust success in alleviating poverty by BRAC operations.

1. Observation indicates that BRAC lends money to low income generating sectors by which complete poverty alleviation is quite impossible. Realising this fact borrower becomes reluctant to involve themselves into microfinance programs rigorously even after taking loan. BRAC therefore, could look into moderate and high income generating employment sectors to divert borrowers to self-employed occupations.

2. Data shows that daily income of each borrower is less than $\$ 2$ after being involved with microfinance and poverty alleviation by this amount of income of a household having 2-3 members is quite difficult and unrealistic as well. Considering this fact, MFIs could emphasise on household poverty alleviation by incorporating all members of the household rather than only women member (usually wives). In that case, volume of income of the household may be improved.

3. To enlarge the volume of savings, MFIs could concentrate on attitudinal change of the borrowers towards large volume of savings and try to make them realise that large amount of savings reduces vulnerability in the livelihood.

4. To build a durable and permanent house, a large amount of money is required which is not affordable by marginal income of the borrowers. BRAC therefore, could provide housing loan to the borrowers on flexible terms and interest and technical assistance to the clients on how to build a durable and permanent house at a minimum costs.

\section{References}

Adams, S., \& Bartholomew, A. T. (2010). The impact of microfinance on maize farmers in Nkoranza (Brong Ahafo Region of Ghana). Journal of Management Research, 2(2), 1-13.

Ahmed, S. (2004). Microcredit and poverty: New realities and strategic issues. In S. Ahmed \& M. A. Hakim (Eds.), Attacking Poverty with Microcredit (2nd ed.) (pp. 23). Dhala-1000, Bangladesh: The University Press Limited.

Ahsan, A. H. M. K. (2005). Role of NGOs health, family planning and education program in poverty reduction in Bangladesh: A study on BRAC. Pakistan Journal of Social Science, 3(8), 1075-1081.

Asian Development Bank (ADB). (2007). Effect of Microfinance Operations on Poor Rural Households and the Status of Women. Special Evaluation Study. Reference Number: SST: REG 2007-19, available at: http://www.oecd.org/dataoecd/46/15/39503711.pdf

Bansal, D. (2011). Impact of microfinance on poverty, employment and women empowerment in rural Punjab. (Doctoral Dissertation). Department of Economics, Punjabi University, Patiala, India. available at: http://hdl.handle.net/10603/3031 
Bauer, A., Hasan, R., Magsombol, R., \& Wan, G. (2008). The World Bank New Poverty Data: Implications for the Asian Development Bank. ADB Sustainable Development Working Paper Series No. 2. Asian Development Bank. available at: http://www.adb.org/Documents/Presntations/New-Poverty-Estimates/Poverty-Data-Implications.pdf

Bedson, J. (2009). Microfinance in Asia-Trends, Challenges and Opportunities (1st ed.). Queensland, Australia: The Foundation for Development Cooperation.

BRAC at a glance. (2009). [online], available at: http://www.brac.net/index.php?nid=16

BRAC net. (n.d.). Overview. [online], available at: http://www.brac.net/index.php?nid=69, accessed on 19/04/2009

Chen, G., Stephen, R., \& Xavier, R. (2010). Growth and Vulnerabilities in Microfinance. Focus Note 61. Washington, D.C.: CGAP. available at: http://www.cgap.org/gm/document-1.9.42393/FN61.pdf

Choudhury, M. O. (2001). An impact assessment of micro-credit programs for rural women-experience of Bangladesh. Journal of the Institute of Bankers Bangladesh, 48, 1-47.

Chowdhury, M., Mosley, P., \& Simaowitz, A. (2004). The social impact of microfinance. Journal of International Development, 16(3), 291-300. http://dx.doi.org/10.1002/jid.1087

Deolalikar, A. B. (2002). Poverty, Growth and Inequality in Thailand. ERD Working Paper Series No. 8, Economics and Research Department. Asian Development Bank.

Develtere, P., \& Huybrechts, A. (2002). Evidence on the social and economic impact of Grameen Bank and BRAC on the poor in Bangladesh. Higher Institute of Labour Studies. Belgium: Katholieke Universiteit Leuven. available at: http://www.hiva.be/docs/paper/p2.pdf

Ghalib, A. K. (2007). Measuring the Impact of Microfinance Intervention: A Conceptual Framework of Social Impact Assessment. The Singapore Economic Review Conference. available at: https://editorialexpress.com/cgibin/conference/download.cgi?db_name=SERC2007\&paper_id=155

Ghalib, A. K., Malki, I., \& Imai, K. S. (2011). The impact of Microfinance and Its Role in Easing of Poverty of Rural Households: Estimations from Pakistan. Discussion Paper Series. Kobe University, Japan. available at: http://www.rieb.kobe-u.ac.jp/academic/ra/dp/English/DP2011-28.pdf

Glazer, S. (2010). Evaluating microfinance: Do small loans for poor entrepreneurs help end poverty? Global Researcher, 4(4), 81-101.

Hossain, M. (2008). Community Development and Livelihood Security: BRAC's Experience in Bangladesh and Afghanistan. The paper presented to The Tokyo Peace builders'Symposium 2008, UN House, Tokyo, March 24-25. available at: http://www.mofa.go.jp/policy/un/pko/symposium0803/hossain.pdf.Google

Hudon, M. (2006). Natural Savings: A New Micro savings Product for Inflationary Environments: How to Save Forests with Savings for and by the Poor? [online], available at: http://www.lietaer.com/images/Natural_Savings_final.pdf

Islam, M. T. (1996). Microcredit: BRAC's approach is holistic, Weekend Independent, The Daily Independent. 6th September, Bangladesh.

Jegede, C., Kehinde, J., \& Akinlabi, B. (2011). Impact of Microfinance on Poverty Alleviation in Nigeria: An Empirical Investigation. European Journal of Humanities and Social Sciences, 2(1), 97-111.

Khondkar, M. (1999). Conceptualization of poverty: The Bangladeshi rural women's experience. Dhaka University Journal of Business Studies, 20(2), 109-136.

Mina, M. S., \& Alam, S. S. (1995). Impact of NGO activities on the development of rural economy of Bangladesh: A case study. The Journal of Finance and Banking, University of Dhaka, 4(1\&2), 20-38.

Murdoch, J., \& Haley, B. (2002). Analysis of the Effects of Microfinance on Poverty Reduction. NYU Wagner Working Paper No. 1014. available at: www.nyu.edu/wagner/publichtml/cgi-bin/workingPapers/wp1014.pdf

Noreen, U. (2010). Impact of Microfinance on Poverty, Pakistan Research Repository. (Doctoral Dissertation). Foundation University, Islamabad. [online], available at: http://eprints.hec.gov.pk/6462/

Okpara, G. C. (2010). Microfinance bank and poverty alleviation in Nigeria. Journal of Sustainable Development in Africa, 12(6), 177-191.

Panjaitan-Drioadisuryo, R. D. M., \& Cloud, K. (1999). Gender, self-employment and microcredit programs: An Indonesian case study. The Quarterly Review of Economics and Finance, 39(5), 769-779. http://dx.doi.org/10.1016/S1062-9769(99)00028-9 
Rahman, M. M. et al. (2001). Micro-credit: A sharp weapon for economic employment of rural women. Journal of Development Review, 13(1\&2), 99-105.

Reddy, G. N. (2000). Empowering Women through Microcredit and Income-Generating Activities. In Towards Empowering Women- Microcredit and Social Mobilization. Report of the Workshop on Capacity Building and Empowerment of Women Self-Help Groups through Microcredit and Social Mobilization, CIRDAP, Bangkok, Thailand.

Sengupta, R., \& Aubuchon, C. P. (2008). The microfinance revolution: An overview. Federal Reserve Bank of St Louis Review, 90(1), 9-30.

Setboonsarng, S., \& Parpiev, Z. (2008). Microfinance and the Millennium Development Goals in Pakistan: Impact Assessment Using Propensity Score Matching. ADB Institute Discussion Paper No. 104. available at: http://www.adbi.org/discussion-paper/2008/04/18/2526.microfinance.millennium.dev.goals

Shah, A. (2008). Poverty Around The World - Global Issues. [online], available at: http://www.globalissues.org/article/4/poverty-around-the-world

Shah, A. (2009). Poverty facts and Stats - Global Issues. [online], available at: http://www.globalissues.org/article/26/poverty-facts-and-stats

Shamsuddoha, M. (2005). Livestock Development through NGOs in Bangladesh: A study on BRAC. [online], available at: http://www.ssrn.com/abstract=1302276

Subrahmanyam, P. (2000). Capacity Building and Empowerment of Women Self-Help Groups through Microcredit and Social Mobilization - An Overview. In Towards Empowering Women-Microcredit and Social Mobilization. CIRDAP Action Research Series, Vol. 27, Bangladesh.

Swope, T. (2005). Microfinance and Poverty Alleviation. (Dissertation Paper). available at: www.rollins.edu/olin/rurj/mpa.pdf

The Daily Star. (2009). Bangladesh News Paper, Business Page-Currency. available at: http://www.thedailystar.net/newDesign/news-details.php?nid=84075

Wright, G. (1999). A Critical Review of Savings Services in Africa and Elsewhere. Working Paper. Nairobi: MicroSave.

Yunus, M. (2004). Expanding Microcredit Outreach to Reach the Millennium Development Goals: Some Issues for Attention. In S. Ahmed \& M. A. Hakim (Eds.), Attacking Poverty with Microcredit (2nd ed.) (pp. 7-22). Dhaka-1000, Bangladesh: The University Press Limited.

\section{Notes}

Note 1. As of $15^{\text {th }}$ April 2009, \$1 Tk. 69, source: The Daily Star, Bangladesh, 14th April, 2009.

Table 1. Changes of Occupation Pattern of the Respondents

\begin{tabular}{|c|c|c|c|c|c|c|c|c|c|c|}
\hline \multirow{2}{*}{ Pattern of Occupation } & & \multicolumn{4}{|c|}{ Before Joining BRAC } & \multicolumn{4}{|c|}{ After Joining BRAC } & \multirow[b]{2}{*}{$\%$ of Changes } \\
\hline & & \multicolumn{2}{|c|}{$\begin{array}{l}\text { No. of } \\
\text { Respondents }\end{array}$} & \multicolumn{2}{|l|}{$\%$} & \multicolumn{2}{|c|}{$\begin{array}{l}\text { No. of } \\
\text { Respondents }\end{array}$} & \multicolumn{2}{|l|}{$\%$} & \\
\hline \multicolumn{2}{|l|}{ Unemployed } & \multicolumn{2}{|c|}{68} & \multicolumn{2}{|c|}{$32 \%$} & \multicolumn{2}{|c|}{0} & \multicolumn{2}{|l|}{0} & $100(-)$ \\
\hline Daily Labour & \multirow{3}{*}{ Low paid works } & 40 & \multirow{3}{*}{66} & 19 & \multirow{3}{*}{$31 \%$} & 11 & \multirow{3}{*}{15} & 5 & \multirow{3}{*}{$7 \%$} & $72(-)$ \\
\hline Maid Serving & & 15 & & 7 & & 2 & & 1 & & $87(-)$ \\
\hline Rice Husking & & 11 & & 5 & & 2 & & 1 & & $82(-)$ \\
\hline Agriculture (Share Cropping) & \multirow{10}{*}{$\begin{array}{l}\text { Selfemployment } \\
\text { works }\end{array}$} & 12 & \multirow{10}{*}{74} & 6 & \multirow{10}{*}{$37 \%$} & 25 & \multirow{10}{*}{193} & 12 & \multirow{10}{*}{$93 \%$} & $108(+)$ \\
\hline Handicrafts and Artisan & & 16 & & 8 & & 32 & & 15 & & $100(+)$ \\
\hline Poultry Farming & & 5 & & 2 & & 16 & & 8 & & $220(+)$ \\
\hline Petty Business & & 25 & & 13 & & 33 & & 15 & & $32(+)$ \\
\hline Livestock Rearing and Fattening & & 8 & & 4 & & 25 & & 12 & & $212(+)$ \\
\hline Fishery & & 0 & & 0 & & 10 & & 5 & & High Increase \\
\hline Nursery & & 4 & & 2 & & 22 & & 11 & & $450(+)$ \\
\hline Bee Keeping & & 2 & & 1 & & 6 & & 3 & & $200(+)$ \\
\hline Tailoring (Sewing) & & 2 & & 1 & & 20 & & 10 & & $900(+)$ \\
\hline Small Cottage (Weaving) & & 0 & & 0 & & 4 & & 2 & & High Increase \\
\hline Total & & \multicolumn{2}{|l|}{208} & \multicolumn{2}{|c|}{100} & \multicolumn{2}{|c|}{208} & \multicolumn{2}{|l|}{100} & \\
\hline
\end{tabular}

Source: Field Survey, 2009.

Note: Figures are rounded to the nearest whole number. 
Table 2. Changes of Monthly Income

\begin{tabular}{|c|c|c|c|c|c|c|}
\hline \multirow{2}{*}{$\begin{array}{l}\text { Length of Attachment } \\
\text { (Year) }\end{array}$} & \multirow{2}{*}{$\begin{array}{l}\text { No. of Respondents } \\
n=208\end{array}$} & \multicolumn{3}{|c|}{ Average per capita Income (Tk) } & \multirow{2}{*}{$\begin{array}{l}\text { Changes of Per } \\
\text { Capita Income (Tk.) }\end{array}$} & \multirow{2}{*}{$\begin{array}{l}\text { \% of } \\
\text { Changes }\end{array}$} \\
\hline & & \multicolumn{2}{|c|}{ Before Joining BRAC } & After Joining BRAC & & \\
\hline 3 & 45 & \multicolumn{2}{|c|}{1211} & 3500 & 2289 & $189(+)$ \\
\hline 4 & 32 & \multicolumn{2}{|l|}{1210} & 3890 & 2680 & $221(+)$ \\
\hline 5 & 53 & \multicolumn{2}{|l|}{1200} & 3920 & 2720 & $227(+)$ \\
\hline 6 & 32 & \multicolumn{2}{|l|}{1050} & 4000 & 2950 & $281(+)$ \\
\hline 7 & 24 & \multicolumn{2}{|l|}{958} & 4200 & 3242 & $338(+)$ \\
\hline 8 & 16 & \multicolumn{2}{|l|}{860} & 4410 & 3550 & $413(+)$ \\
\hline 9 and above & 6 & \multicolumn{2}{|l|}{850} & 4500 & 3650 & $429(+)$ \\
\hline \multicolumn{2}{|c|}{ Combined average monthly income } & Tk. 1116.67 & & Tk. 3923.56. & Tk. 2806.89 & $254(+)$ \\
\hline \multicolumn{7}{|c|}{$\begin{array}{l}\text { N.B. Respondents having long attachment with BRAC operations show less income bracket before joining microcredit scheme. It is because, the } \\
\text { inflation rate and minimum wages bracket were lower as many years back compare to survey year. }\end{array}$} \\
\hline \multicolumn{7}{|c|}{$\begin{array}{l}\text { Source: Field Survey, } 2009 . \\
\text { Note: Figures are rounded to the nearest whole number. }\end{array}$} \\
\hline \multicolumn{7}{|c|}{ Table 3. Contributions to Family Expenditure (Monthly) } \\
\hline \multirow{2}{*}{$\begin{array}{l}\text { Heads of } \\
\text { Expenditure }\end{array}$} & \multicolumn{4}{|c|}{ Expenditure Contributed (Tk.) } & \multirow{2}{*}{$\begin{array}{l}\text { Average } \\
\text { changes (Tk.) }\end{array}$} & \multirow{2}{*}{$\begin{array}{l}\text { Average } \\
\text { changes in \% }\end{array}$} \\
\hline & \multicolumn{2}{|c|}{$\begin{array}{l}\text { Before Joining BRAC } \\
\text { (average per month) }\end{array}$} & \multicolumn{2}{|c|}{$\begin{array}{l}\text { After Joining BRAC } \\
\text { (average per month) }\end{array}$} & & \\
\hline Basic Food & \multicolumn{2}{|l|}{$901.24(88 \%)$} & \multicolumn{2}{|c|}{$2374.66(63 \%)$} & $1473.42(+)$ & $163(+)$ \\
\hline Clothing & \multicolumn{2}{|l|}{$48.94(5 \%)$} & \multicolumn{2}{|c|}{$382.58(10 \%)$} & $333.64(+)$ & $682(+)$ \\
\hline Health Care & - & & 145.12 & $5 \%)$ & $145.12(+)$ & High increase \\
\hline Entertainment & - & & 115.98 & $3 \%)$ & $115.98(+)$ & High increase \\
\hline Children's Education & $6.12(1 \%)$ & & 304.45 & $8 \%)$ & $298.33(+)$ & $4875(+)$ \\
\hline Others & $63.20(6 \%)$ & & 420.28 & $11 \%)$ & $357.08(+)$ & $565(+)$ \\
\hline Total & Tk. 1019.30 (100 \%) & & Tk. 37 & $.30(100 \%)$ & Tk. 2750 & $270 \%$ \\
\hline
\end{tabular}

Source: Field Survey, 2009.

Note: Figures are rounded to the nearest whole number.

Table 4. Changes of Monthly Savings Status

\begin{tabular}{|c|c|c|c|c|c|}
\hline \multirow{2}{*}{ Amount of Savings (Tk.) per Month } & \multicolumn{2}{|c|}{ Before Joining BRAC } & \multicolumn{2}{|l|}{ After Joining BRAC } & \multirow{2}{*}{$\%$ of Changes } \\
\hline & No. of Respondents & $\%$ & No. of Respondents & $\%$ & \\
\hline No Savings & 164 & 79 & 0 & 0 & $100(-)$ High Decrease \\
\hline Below 50 & 31 & 15 & 142 & 68 & $358(+)$ \\
\hline $50-100$ & 10 & 5 & 35 & 17 & $250(+)$ \\
\hline $100-150$ & 3 & 1 & 20 & 10 & $567(+)$ \\
\hline $150-200$ & 0 & 0 & 8 & 4 & High Increase \\
\hline 200 and above & 0 & 0 & 3 & 1 & High Increase \\
\hline Total & 208 & 100 & 208 & 100 & \\
\hline
\end{tabular}

Source: Field Survey, 2009.

Note: Figures are rounded to the nearest whole number.

Table 5. Creation of New Employment Opportunity

\begin{tabular}{|c|c|c|c|c|c|}
\hline \multirow{2}{*}{ No. of Income Earners } & \multicolumn{2}{|c|}{ Before Joining BRAC } & \multicolumn{2}{|l|}{ After Joining BRAC } & \multirow{2}{*}{$\%$ of Change } \\
\hline & No. of Respondents & $\%$ & No. of Respondents & $\%$ & \\
\hline Only 1 & 141 & 68 & 47 & 22 & $62(-)$ \\
\hline Only 2 & 50 & 24 & 116 & 56 & $132(+)$ \\
\hline Only 3 & 17 & 8 & 35 & 17 & $106(+)$ \\
\hline Only 4 & 0 & 0 & 10 & 5 & High Increase \\
\hline Total & 208 & 100 & 208 & 100 & \\
\hline
\end{tabular}

Source: Field Survey, 2009.

Note: Figures are rounded to the nearest whole number. 
Table 6. Changes of Dwelling House Condition

\begin{tabular}{|l|l|l|l|l|l|}
\hline \multirow{2}{*}{ Nature of Houses } & \multicolumn{2}{|l|}{ Before Joining BRAC } & After Joining BRAC & \multirow{2}{*}{$\%$ of Changes } \\
\cline { 2 - 7 } & No. of Respondents & $\%$ & No. of Respondents & $\%$ & $20(-)$ \\
\hline House made by Clay and Thatch & 75 & 36 & 60 & 56 & 29 \\
\hline House made by Thatch fully & 107 & 51 & 56 & 27 & $48(-)$ \\
\hline House made by clay and Tin & 26 & 13 & 68 & 33 & $162(+)$ \\
\hline House made by fully Tin & 0 & 0 & 24 & 11 & High Increase \\
\hline Total & $\mathbf{2 0 8}$ & $\mathbf{1 0 0}$ & $\mathbf{2 0 8}$ & $\mathbf{1 0 0}$ & \\
\hline
\end{tabular}

Source: Field Survey, 2009.

Note: Figures are rounded to the nearest whole number.

Table 7. Years of Attachment with BRAC and Amount of Loan Taken by the Respondents

\begin{tabular}{|l|l|l|l|}
\hline Year of Attachment (Years) & Loan Amount Taken (per head) Tk. & No. of Respondents & Average Loan Taken (per head) Tk. \\
\hline 3 & Less than 30000 & $32(15 \%)$ & 15000 \\
\hline 4 & $30000-40000$ & $63(30 \%)$ & 35000 \\
\hline 5 & $40000-50000$ & $47(23 \%)$ & 45000 \\
\hline 6 & $50000-60000$ & $21(10 \%)$ & 55000 \\
\hline 7 & $60000-70000$ & $16(8 \%)$ & 65000 \\
\hline 8 & $70000-80000$ & $23(11 \%)$ & 75000 \\
\hline 9 and above & $80000-100000$ & $6(3 \%)$ & 90000 \\
\hline Total & $\mathbf{2 0 8 ( 1 0 0 \% )}$ & \\
\hline Average loan Taken per head Tk. 44 520.00 & \\
\hline
\end{tabular}

Source: Field Survey, 2009.

Note: Figures are rounded to the nearest whole number. 